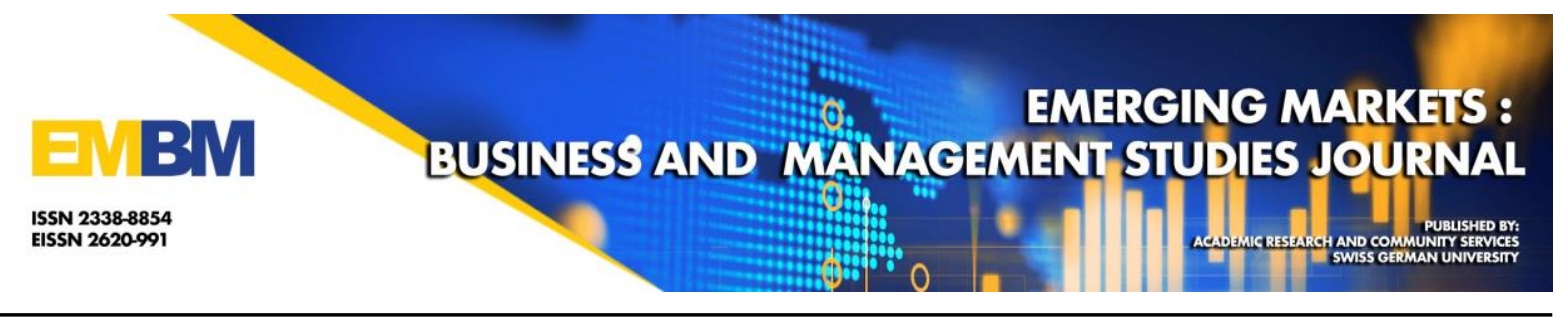

\title{
WHO MOVES WESTERN EUROPE STOCK MARKETS?
}

\section{Robertus Setiadi}

\author{
Partner KJPP Amin, Nirwan, Alfiantori \& Rekan, Jakarta, Indonesia. \\ Research Scholar PPIM FEB Universitas Indonesia
}

\author{
Article Information \\ Received: 11 February 2021 \\ Accepted: 9 June 2021 \\ Published: 5 July 2021 \\ DOI: $10.33555 / \mathrm{embm} . \mathrm{v} 8 \mathrm{i} 1.166$ \\ Corresponding Author: \\ Robertus Setiadi \\ Jakarta, Indonesia \\ Email: setiadi.robertus@gmail.com \\ ISSN 2338-8854 \\ eISSN 2620-9918
}

\begin{abstract}
This paper focuses on short- and long-term causal relationship on six major Stock Exchanges in Western Europe which actively traded, while also considering the interaction with US Stock Exchange. The observation period is separated into 3 sub-samples to represent the pre-crisis period, crisis period, and post-crisis period; while the author also distinguishes between local currency and USD denominations in stock closing price. Conversion of local currency in USD denominations shows an effect on increasing the interdependence shown in the pre-crisis observation while tested using Johansen test. In the whole-period sample, Belgium, Germany, and the US should be considered as dominant country to granger cause the other Western Europe. Longterm relationships were also tested by granger causality showing different characteristics in each sub-sample. Finally, Italy is the most sensitive country in the response to other Western European countries innovations while tested by Generalized Impulse Response Analysis.
\end{abstract}

Keywords: Co-Integration, Financial Crisis, Impulse Response, Stock Market Interdependencies 


\section{Introduction}

Global Financial Crisis occurred in 2008, was followed by a recession that hit most of the world's economies. Dervis \& Kharas (2011) highlighted the importance of financial and macroeconomic stability which is contagious along with globalization. The transformation carried out by the Financial Stability Board (FSB) also emphasized the financial crisis and macroeconomic interdependence. Coordination of fiscal, monetary, and exchange rate policies from major countries are naturally considered to be able to influence other countries, in connection with the spillover effects of macroeconomic policies.

In line with globalization, one of the platforms for investors to allocate their wealth is through stock exchanges, both domestic and foreign. According to Gupta et.al (2019) diversification investment strategy in the stock exchanges of countries with a higher correlation will result in failure to achieve higher returns with optimal risk mitigation. Some investment considerations include variance, covariance, and correlation which are found on various asset options in the portfolio. So the analysis of financial market integration is important for hedging risk and maximizing returns.

In testing the integration and causality of interdependencies, Wang (2014) research focuses on the contagion transmittance or transmission of the US stock market to the East Asian stock market. In addition, there were differences in dependency characteristics between stock markets which increased during the crisis period, in line with the weakening influence of the US stock market. The US influence is relatively crucial in examining the relationship between stock markets; as in the research of Cheung et.al (2010) which also considers TED spread as a proxy for credit risk, so there are implications for determining the treasury bills rate. Meanwhile, Wang
(2014) tested short-term causal relationships with impulse response analysis.

Several studies have focused on stock market relations of countries with which trade relations regionally. Kumar (2019) tests the dynamic linkages among South Asian stock which are member of SAFTA. Besides, Rahman et.al (2017) was also investigate the linkages between ASEAN regional country stock indexes, while adding three other countries outside ASEAN.

The European Union (EU) initiation in 1999 began to introduce currency uniformity to member countries, with the aim of increasing global competitiveness. Included in the group of developed countries, GDP per capita of the majority member countries is greater than the world average. The author takes a sample of 6 countries in the Western Europe, including UK, Germany, France, Belgium, Netherlands, and Italy. Sammader (2018) paper which investigates integration between Indian stock markets and developed stock markets, also accounted several Western Europe countries such as France, Germany, and UK.

The approach taken in the research of Vodenska et.al (2016) in observing the relationship between financial networks also considers the lead-lag and the division of observation periods into the classification of mild crisis, calm, and severe crisis to distinguish the characteristics per period.

Hence, this research is intended to answer several questions such as (1) Does the financial crisis change the interdependencies among Western Europe stock market, compared to pre-crisis period and postcrisis period? (2) Which countries are influential in driving the other Western Europe stock market in the long run during pre-crisis period, crisis period, and postcrisis period? (3) Which is the most sensitive country in the response to other 
Western European countries innovations? Taking into account the active trading on the stock exchange and the market capitalization of some of the countries of Western Europe that exceeds one trillion US Dollar, it is essential to conduct research in observing short-run and long-run relationship in the stock market for the investment strategy, while taking into account the influence from US stock market.

\section{Literature Review}

Integration of stock markets could be an interesting topic due to diversification opportunity for investors around the world. However, we often come across conflicting result from existing literature. Gupta et.al (2019) highlight the conflicting result could be explained by the different use of data frequency and methodology.

The differences in characteristics in each sub-sample period are shown in Vodenska et.al (2016) research. During severe crisis period sub-sample, they find that the interactions between foreign exchange and equity market are very strong. However, various characteristic of each sub-sample might be influenced by different macroeconomic conditions. During mild crisis sub-sample (before crisis period), global equity markets have the highest predictive power to explain currency return compared to another period.

The majority of interdependency topic research always incorporates the influence of US Stock Exchange or US subprime crisis. For instance, Kumar (2019) confirmed a structural break in research data. Moreover, Sammader (2018) and Wang (2014) paper also includes US as one of the most influential country. Wang (2014) paper implemented the Johansen test based on the VAR modeling. According to Johansen (1991), VAR modeling can also be combined with the error correction term, reflected in $\pi \mathrm{X}_{\mathrm{t}-1}$.
Hence, in accordance with globalization and macroeconomic interdependence, investors are triggered to find potential arbitrage gain in the long run, while also considering short-run response in innovation. Sammader (2018) findings state that though investors might benefit from short-run portfolio diversification, long-run benefits are still restricted.

\section{Data and Methodology}

In this paper, data obtained through Bloomberg Terminal consists of daily closing prices for 6 stock exchanges in Western Europe which are quite dominant and actively traded, including the UKX Index (United Kingdom), DAX Index (Germany), CAC Index (France), BEL20 Index (Belgium), AEX Index (Netherlands), FTSE MIB Index (Italy). In addition, data on the US Stock Exchange was also collected, namely the US S\&P 500 Composite Index (US). Apart from using the local currency, the authors convert the closing stock price of each country in US\$. The denomination technique was also applied in a similar study by Ahmedov (2010) which examined several countries in Asia.

The entire study period is May $14^{\text {th }}, 1999$ to December $31^{\text {st }}, 2019$ with a total of 5,294 observations. Then the pre-crisis try period is described in the period from May $14^{\text {th }}$, 1999 to December $31^{\text {st }}, 2007$ (2215 observations). The European sovereign debt crisis, which began in 2008 with the collapse of Iceland banks, marked the Great Recession period that took place from 2008 to 2012, with the peak of the crisis in 20102012. The author tries to capture the crisis period with a sub-sample period from January $1^{\text {st }}, 2008$ to December $31^{\text {st }}, 2012$ (1286 observations). Meanwhile, the postcrisis period covers January $1^{\text {st }}, 2013$ to December $31^{\text {st }}, 2019$ (1793 observations). In connection with the Covid-19 pandemic, 2020 year is not included in the observation period. 
Table 1. Descriptive Statistic

Source: daily stock index closing price, Bloomberg Terminal

\begin{tabular}{|c|c|c|c|c|c|c|c|}
\hline \multicolumn{8}{|c|}{ Descriptive Statistics (in basis point) } \\
\hline & Belgium & France & Germany & Italy & Netherlands & UK & US \\
\hline \multicolumn{8}{|c|}{ Whole Period : $14 / 5 / 1999$ - 31/12/2019 } \\
\hline Mean & 0.424 & 0.612 & 1.780 & -0.843 & 0.173 & 0.340 & 1.890 \\
\hline Median & 3.090 & 3.410 & 6.960 & 3.770 & 4.750 & 2.340 & 5.380 \\
\hline $\operatorname{Max}(\%)$ & 9.334 & 10.594 & 10.797 & 10.874 & 10.028 & 9.384 & 10.957 \\
\hline $\operatorname{Min}(\%)$ & -8.319 & -9.471 & -8.874 & -13.314 & -9.590 & -9.265 & -9.469 \\
\hline Stdev $(\%)$ & 1.209 & 1.396 & 1.440 & 1.480 & 1.366 & 1.145 & 1.187 \\
\hline \multicolumn{8}{|c|}{ Pre-Crisis Period : 14/5/1999 - 31/12/2007 } \\
\hline Mean & 1.210 & 1.180 & 2.010 & 0.219 & -0.308 & 0.111 & 1.210 \\
\hline Median & 3.530 & 3.820 & 8.540 & 5.910 & 4.880 & 2.990 & 4.160 \\
\hline $\operatorname{Max}(\%)$ & 9.334 & 7.002 & 7.552 & 7.627 & 9.516 & 5.903 & 5.573 \\
\hline $\operatorname{Min}(\%)$ & -5.610 & -7.678 & -8.874 & -7.866 & -7.531 & -5.885 & -4.414 \\
\hline Stdev (\%) & 1.147 & 1.371 & 1.525 & 1.215 & 1.423 & 1.124 & 1.114 \\
\hline \multicolumn{8}{|c|}{ Crisis Period : 1/1/2008 - 31/12/2012 } \\
\hline Mean & -3.970 & -3.370 & -0.451 & -6.710 & -3.180 & -0.704 & -0.900 \\
\hline Median & -0.619 & -0.049 & 4.140 & 0.000 & 0.000 & 0.000 & 7.260 \\
\hline $\operatorname{Max}(\%)$ & 9.221 & 10.594 & 10.797 & 10.874 & 10.028 & 9.384 & 10.957 \\
\hline $\operatorname{Min}(\%)$ & -8.319 & -9.471 & -7.433 & -8.599 & -9.590 & -9.265 & -9.469 \\
\hline Stdev (\%) & 1.607 & 1.806 & 1.715 & 1.971 & 1.720 & 1.505 & 1.659 \\
\hline \multicolumn{8}{|c|}{ Post-Crisis Period : 1/1/2013 - 31/12/2019 } \\
\hline Mean & 2.610 & 2.770 & 3.090 & 2.050 & 3.170 & 1.370 & 4.740 \\
\hline Median & 4.140 & 5.320 & 6.980 & 3.950 & 6.470 & 4.130 & 5.920 \\
\hline $\operatorname{Max}(\%)$ & 3.801 & 4.060 & 4.852 & 5.698 & 3.970 & 3.515 & 4.840 \\
\hline $\operatorname{Min}(\%)$ & -6.613 & -8.384 & -7.067 & -13.331 & -5.873 & -4.779 & -4.184 \\
\hline Stdev (\%) & 0.918 & 1.047 & 1.067 & 1.361 & 0.941 & 0.830 & 0.809 \\
\hline
\end{tabular}

Table 1 provides a summary of daily returns in local currency (log-transformed) stock exchanges in Western Europe and the US by whole period, pre-crisis period, crisis period, and post-crisis period. In the entire observation period, the performance of US mean stock returns is greater than all Western Europe countries. Likewise, volatility is reflected in the US standard deviation which is consistently smaller in the whole period, pre-crisis, crisis and postcrisis.

Different characteristics can be seen during the crisis period, where the US standard deviation was recorded at $1.659 \%$, which is higher than Belgium and the UK at $1.607 \%$ and $1.505 \%$, respectively. The authors also believe that January $1^{\text {st }}, 2008$ to December $31^{\text {st }}, 2012$ period already represents crisis period; with a negative mean in all sample countries during that period.

In contrast, during whole-period observation, only Italy stock exchange recorded mean at -0.843 basis points. On the other hand, during pre-crisis period observation, only Netherlands stock exchange recorded mean at -0.308 basis points.

\section{Results and Discussion}

Table 2 illustrates the unit root test on the log-transformed index of stock exchanges of all sample countries. By applying a 5\% critical value, the Augmented DickeyFuller and Phillips-Perron tests consistently state that the series is I (1), and is stationary. 
Table 2. Unit Root Test

Source: Author, 2020

\begin{tabular}{lllll}
\hline & \multicolumn{2}{l}{ Augmented Dickey-Fuller } & \multicolumn{2}{l}{ Phillips-Perron } \\
\hline Return Series & Prob. & Lag & Prob. & Bandwidth \\
Belgium & 0.0001 & 0 & 0.0001 & 0 \\
France & 0.0000 & 4 & 0.0001 & 24 \\
Germany & 0.0001 & 0 & 0.0001 & 11 \\
Italy & 0.0001 & 0 & 0.0001 & 8 \\
Netherlands & 0.0000 & 4 & 0.0001 & 9 \\
UK & 0.0000 & 4 & 0.0001 & 11 \\
US & 0.0001 & 1 & 0.0001 & 23 \\
\hline
\end{tabular}

Long-Run Equilibrium Relationship (Cointegration)

The initial step of Long-run Equilibrium relationship testing is to determine the optimal lag-length with the likelihood ratio test, with the parameters used is a maximum lag of 15 days. By considering the characteristics of the data, the assumptions used are modeling with intercept, and no time trend. The indicator used is a combination of Akaike Information Criterion (AIC), Schwarz Criterion (SC), and Hannan Quinn (HQ) Criterion. If there are conflicting results between AIC and SC, the author will determine the Hannan Quinn Criterion as the optimum lag.

Table 3 explains the VAR Lag Order Selection Criteria for the whole period, precrisis period, crisis period, and post-crisis period in local currency price index, which are respectively 2, 2, 1, and 1 . By converting the local currency to USD, we find that the VAR Lag Order is not much different, which are respectively $3,2,1$, and 1.

Table 3. VAR Lag Order Selection Criteria

Source: Author, 2020

\begin{tabular}{lcll}
\hline \multicolumn{2}{c}{ Local Currency } & \multicolumn{2}{c}{ US Dollar } \\
\hline Observation Period & Lag Order & Observation Period & Lag Order \\
Whole Period & 2 & Whole Period & 3 \\
Pre-Crisis Period & 2 & Pre-Crisis Period & 2 \\
Crisis Period & 1 & Crisis Period & 1 \\
Post-Crisis Period & 1 & Post-Crisis Period & 1 \\
\hline
\end{tabular}

Long run relationship tested using Johansen Co-integration test on a 7-dimensional VAR model. With a critical value of $5 \%$, the $\lambda$ trace statistic will be compared with $\lambda$ based on this critical value. 
Table 4. Johansen Test (Local Currency \& USD) Source: Author, 2020

\begin{tabular}{lllll}
\hline & $\lambda_{\text {trace }}$ Statistic (local) & $\lambda_{\text {trace }}$ Statistic (USD) & 5\% Critical Value & \multirow{2}{*}{ Prob. (local) } \\
\hline & Panel A : Whole Period (14/5/1999- 31/12/2019) & \\
$\mathbf{r = 0}$ & $\mathbf{1 5 2 . 0 6 5 9}$ & $\mathbf{1 3 8 . 0 7 7 4}$ & 125.6154 & 0.0005 \\
$\mathbf{r} \leq \mathbf{1}$ & $\mathbf{9 5 . 8 1 8 6 0}$ & 84.95166 & 95.75366 & 0.0495 \\
$\mathbf{r} \leq \mathbf{2}$ & 56.84195 & 45.95119 & 69.81889 & 0.3449 \\
$\mathbf{r} \leq \mathbf{3}$ & 31.50965 & 25.21041 & 47.85613 & 0.6930 \\
$\mathbf{r} \leq \mathbf{4}$ & 9.840256 & 10.42934 & 29.79707 & 0.9826 \\
$\mathbf{r} \leq \mathbf{5}$ & 3.264529 & 2.839009 & 15.49471 & 0.9536 \\
$\mathbf{r} \leq \mathbf{6}$ & 1.253606 & 0.618201 & 3.841466 & 0.2629 \\
\end{tabular}

Panel B : Pre-Crisis Period (14/5/1999 - 31/12/2007)

\begin{tabular}{|c|c|c|c|c|}
\hline $\mathbf{r}=\mathbf{0}$ & 145.6623 & 166.2049 & 125.6154 & 0.0017 \\
\hline $\mathbf{r} \leq \mathbf{1}$ & 87.76446 & 109.1123 & 95.75366 & 0.1562 \\
\hline $\mathbf{r} \leq 2$ & 53.82899 & 64.19487 & 69.81889 & 0.4690 \\
\hline $\mathbf{r} \leq \mathbf{3}$ & 27.19745 & 30.62015 & 47.85613 & 0.8467 \\
\hline$r \leq 4$ & 12.36277 & 17.13050 & 29.79707 & 0.9185 \\
\hline $\mathbf{r} \leq \mathbf{5}$ & 3.769243 & 5.171822 & 15.49471 & 0.9213 \\
\hline \multirow[t]{2}{*}{$r \leq 6$} & 1.133046 & 0.060155 & 3.841466 & 0.2871 \\
\hline & \multicolumn{4}{|c|}{ Panel C : Crisis Period (1/1/2008 - 31/12/2012) } \\
\hline $\mathbf{r}=\mathbf{0}$ & 141.6505 & 136.8776 & 125.6154 & 0.0036 \\
\hline$r \leq 1$ & 95.03241 & 88.33245 & 95.75366 & 0.0560 \\
\hline$r \leq 2$ & 64.70535 & 56.47799 & 69.81889 & 0.1196 \\
\hline$r \leq 3$ & 41.23939 & 34.72062 & 47.85613 & 0.1812 \\
\hline$r \leq 4$ & 20.69873 & 16.79797 & 29.79707 & 0.3767 \\
\hline$r \leq 5$ & 7.146098 & 6.332102 & 15.49471 & 0.5607 \\
\hline$r \leq 6$ & 0.802295 & 0.384653 & 3.841466 & 0.3704 \\
\hline
\end{tabular}

Panel D :Post- Crisis Period (1/1/2013 - 31/12/2019)

\begin{tabular}{lllll}
$\mathbf{r}=\mathbf{0}$ & $\mathbf{1 6 6 . 0 0 2 0}$ & $\mathbf{1 2 5 . 7 7 9 4}$ & 125.6154 & 0.0000 \\
$\mathbf{r} \leq \mathbf{1}$ & 83.83907 & 86.00602 & 95.75366 & 0.2481 \\
$\mathbf{r} \leq \mathbf{2}$ & 46.56618 & 53.03636 & 69.81889 & 0.7771 \\
$\mathbf{r} \leq \mathbf{3}$ & 20.61385 & 29.65810 & 47.85613 & 0.9874 \\
$\mathbf{r} \leq \mathbf{4}$ & 9.622135 & 12.57154 & 29.79707 & 0.9853 \\
$\mathbf{r} \leq \mathbf{5}$ & 3.907501 & 5.383277 & 15.49471 & 0.9109 \\
$\mathbf{r} \leq \mathbf{6}$ & 0.127116 & 0.665520 & 3.81466 & 0.7213 \\
\hline
\end{tabular}

Table 4 Panel A explains that there are 2 cointegrating vectors based on $\lambda_{\text {trace }}$ statistics value for the entire observation period using the stock exchange closing price in the local currency. Different long-term relationship characteristics are shown in the $\lambda_{\text {trace }}$ statistical test for the entire observation period with USD currency which only has 1 co-integrating vector.

The author determines the lag order according to Table 3 based on the sub- sample observation period and currency. In Panel B, the observation period was set on May $14^{\text {th }}, 1999$ to December $31^{\text {st }}, 2007$, where one co-integrating vector was found, which means that there is a long-term relationship between the stock exchanges in Western Europe during pre-crisis observation.

When considering the effect of USD conversion, there is an increase in the interdependence indicated by 2 co- 
integrating vectors. This interpretation is in line with the research of Bessler \& Yang (2003), which found that changes in exchange rate can affect the long-term cointegrating relationship between stock markets. This result is also in line with Vodenska et.al (2016) paper which finds that interactions between foreign exchange and equity market are stronger during precrisis period.

Based on Panel C and Panel D, it was found that in the crisis period and post-crisis period sub-samples, there was a long-term consistent relationship with $\lambda_{\text {trace }}$ statistic $>$ $\lambda$ based on a critical value of $5 \%$ at $r=0$. In the crisis and post-crisis periods the same conclusion was obtained, while taking into account the conversion of the USD exchange rate.

\section{Interdependencies among Western Europe Stock Markets}

Wang (2014) research also tested the multivariate Granger Causality Test in each sub-sample of the observation period. Along with this test, we can see the effect of the US stock exchange on the Western Europe stock market. By considering the significant effect on the lag, the criteria lag test is determined in advance with a maximum parameter of 15 days. In the precrisis period and post-crisis observation periods, Wang (2014) used VAR, while in the crisis period the VEC Model was used at the data level.

Table 5 Panel A explains that in the entire observation period, from May $14^{\text {th }}, 1999$ to December $31^{\text {st }}, 2019$ with 2 lags effect, there are several countries that predominantly influence the price index of other countries. Belgium significantly affects / granger cause Germany, Italy, Netherlands, and UK with prob. $<5 \%$. Meanwhile, Germany granger causes France, Italy, Netherlands and UK. The influence of the US stock index is quite significant on the stock index of Western Europe countries, as it granger causes Belgium, France, and Netherlands.

Table 5. Granger Causality Test (Local Currency)

Source: Author, 2020

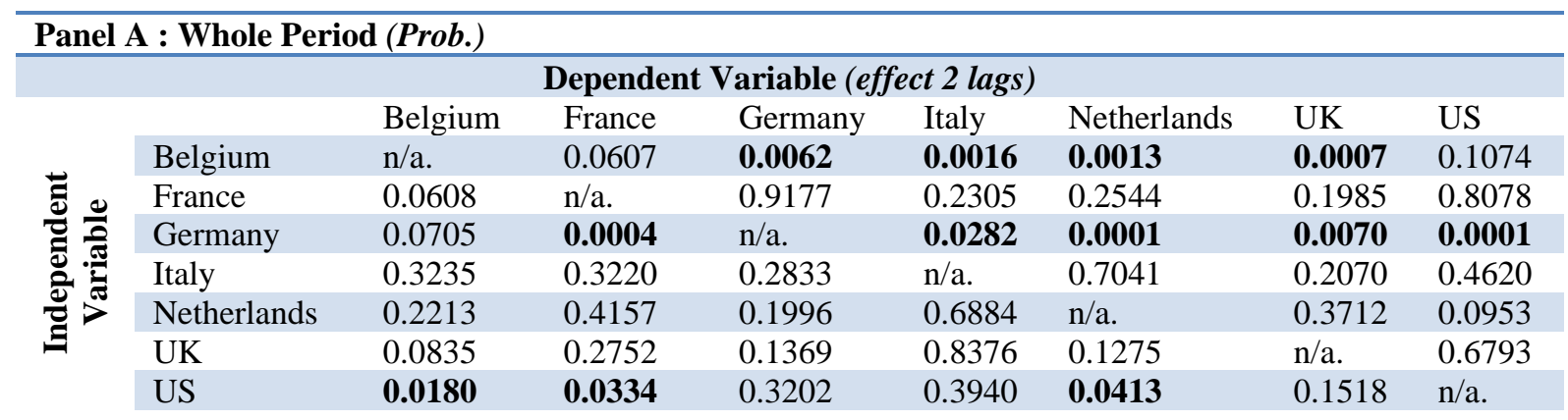

Panel B : Pre-Crisis Period (Prob.)

\begin{tabular}{|c|c|c|c|c|c|c|c|c|}
\hline \multicolumn{9}{|c|}{ Dependent Variable (effect 2 lags) } \\
\hline \multirow{8}{*}{ 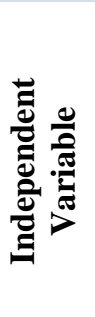 } & & Belgium & France & Germany & Italy & Netherlands & UK & US \\
\hline & Belgium & n/a. & 0.0639 & 0.0716 & 0.0956 & 0.0003 & 0.0283 & 0.5660 \\
\hline & France & 0.0951 & $\mathrm{n} / \mathrm{a}$. & 0.5752 & 0.1017 & 0.2874 & 0.1073 & 0.2110 \\
\hline & Germany & 0.0097 & 0.0000 & n/a. & 0.0218 & 0.0000 & 0.0002 & 0.0051 \\
\hline & Italy & 0.5742 & 0.6325 & 0.8986 & $\mathrm{n} / \mathrm{a}$. & 0.8575 & 0.0933 & 0.7858 \\
\hline & Netherlands & 0.0075 & 0.0152 & 0.0064 & 0.0716 & n/a. & 0.0929 & 0.9445 \\
\hline & UK & 0.0322 & 0.1039 & 0.0088 & 0.1038 & 0.0057 & $\mathrm{n} / \mathrm{a}$. & 0.4619 \\
\hline & US & 0.2239 & 0.1927 & 0.3735 & 0.7520 & 0.3117 & 0.0474 & $\mathrm{n} / \mathrm{a}$. \\
\hline
\end{tabular}




\begin{tabular}{|c|c|c|c|c|c|c|c|c|}
\hline \multicolumn{9}{|c|}{ Panel C : Crisis Period (Prob.) } \\
\hline \multirow{8}{*}{ 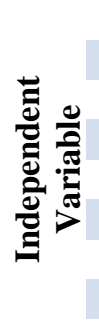 } & & Belgium & France & Germany & Italy & Netherlands & UK & US \\
\hline & Belgium & n/a. & 0.0059 & 0.0116 & 0.0016 & 0.0008 & 0.0035 & 0.8080 \\
\hline & France & 0.1230 & n/a. & 0.2963 & 0.7071 & 0.0369 & 0.0856 & 0.9093 \\
\hline & Germany & 0.8349 & 0.3743 & n/a. & 0.8613 & 0.8143 & 0.4292 & 0.3571 \\
\hline & Italy & 0.7111 & 0.5407 & 0.4743 & n/a. & 0.6239 & 0.8623 & 0.4013 \\
\hline & Netherlands & 0.7402 & 0.6151 & 0.9185 & 0.5151 & $\mathrm{n} / \mathrm{a}$. & 0.3160 & 0.2484 \\
\hline & UK & 0.6116 & 0.9314 & 0.8679 & 0.3536 & 0.2317 & n/a. & 0.4331 \\
\hline & US & 0.2403 & 0.1983 & 0.1576 & 0.1159 & 0.1309 & 0.3502 & $\mathrm{n} / \mathrm{a}$ \\
\hline
\end{tabular}

Panel D : Post-Crisis Period (Prob.)

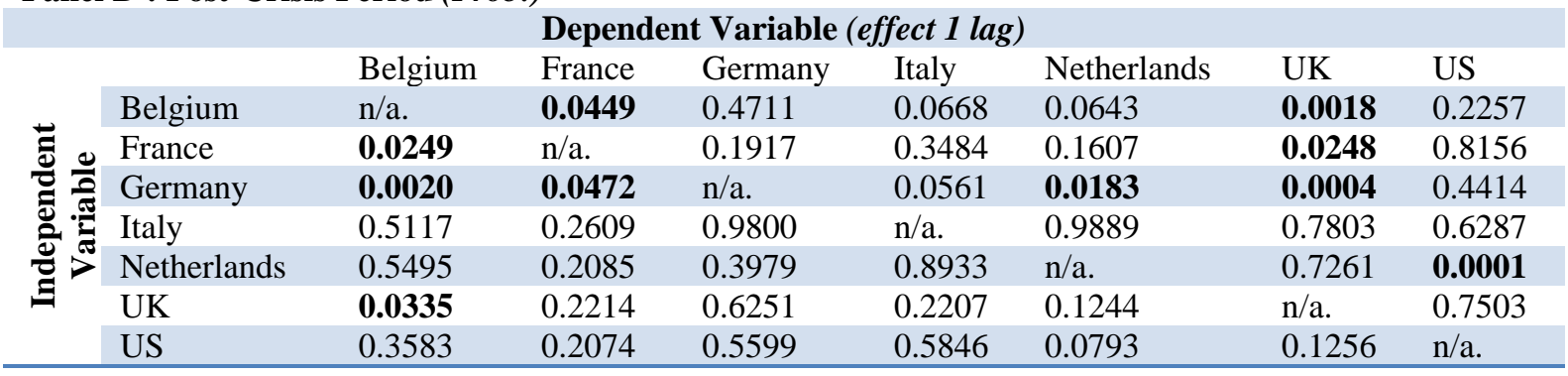

Panel B, which depicts the pre-crisis observation period, illustrates the strong relationship between the indexes between countries in Western Europe. During this period, there are several countries which are influential as an independent variable, namely the stock indexes of Belgium, Germany, Netherlands, and the UK. Observations show that time-varying subsamples produce different long-term relationships. During the crisis period, Panel $\mathrm{C}$ explained that Belgium granger causes France, Germany, Italy, Netherlands, and UK. Meanwhile, only France Granger causes Netherlands. Hence, during the crisis period, long-term relations did not significantly appear in Western Europe countries.

The dominance of the countries of Belgium and Germany in influencing share prices in Western Europe was also confirmed during the post-crisis period which is identical to the whole period. However, we can observe a non-significant effect of the United States on the observed sub-sample period. However, in the long term from May $14^{\text {th }}$, 1999 to December $31^{\text {st }}, 2019$, US granger causes Belgium, France, and Netherlands.

Table 6. Granger Causality Test (USD Currency)

Source: Author, 2020

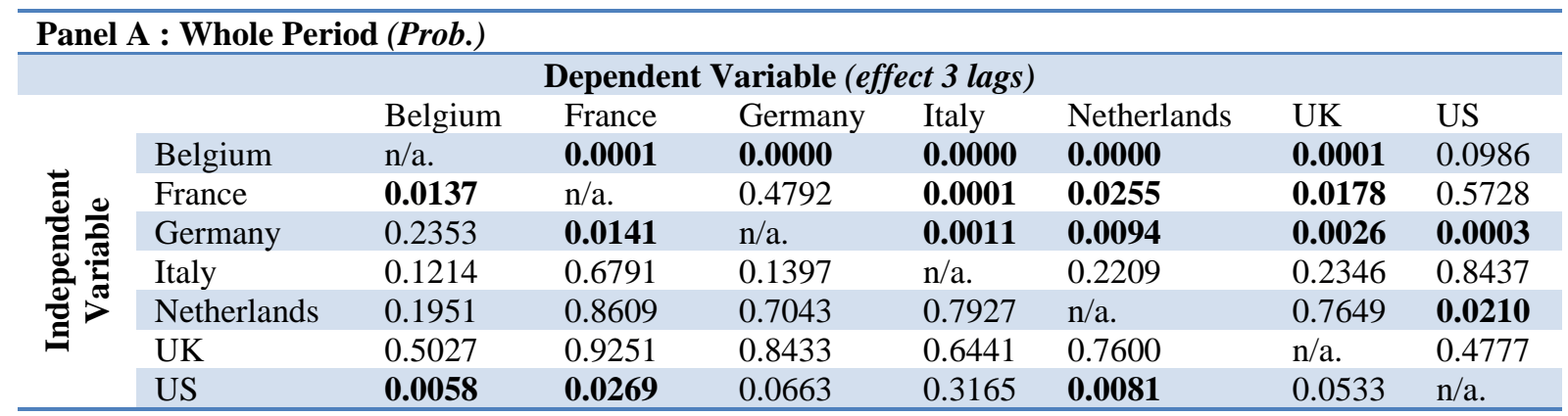




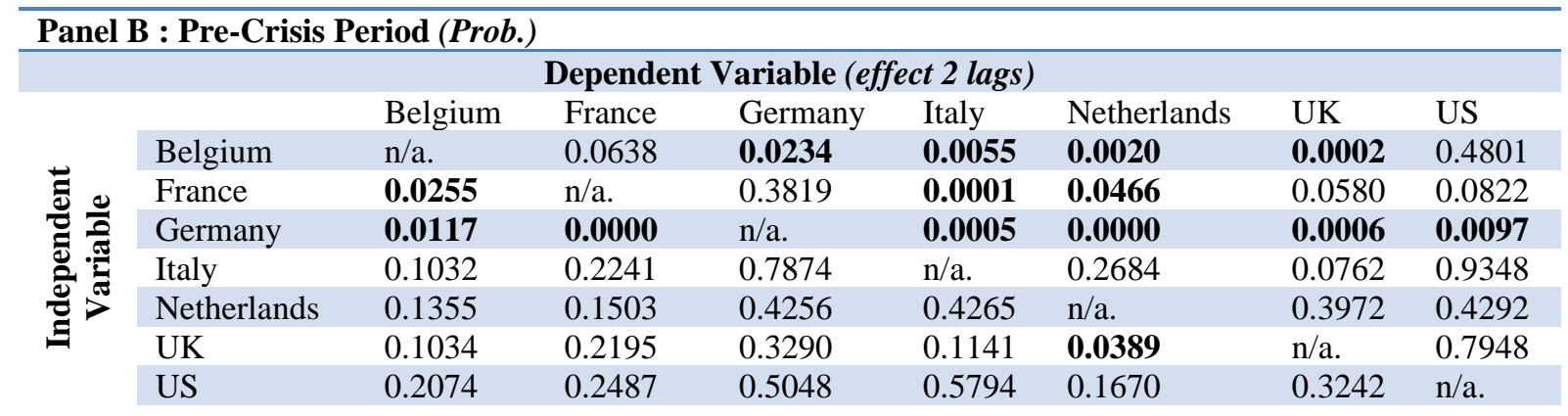

Panel C : Crisis Period (Prob.)

\begin{tabular}{|c|c|c|c|c|c|c|c|c|}
\hline & & & Depende & Jariable (e & ct 1 lag & & & \\
\hline & & Belgium & France & Germany & Italy & Netherlands & UK & US \\
\hline & Belgium & n/a. & 0.0005 & 0.0014 & 0.0001 & 0.0001 & 0.0003 & 0.8263 \\
\hline $\overrightarrow{0}$ & France & 0.0408 & n/a. & 0.0634 & 0.1361 & 0.0244 & 0.0021 & 0.8377 \\
\hline 司 & Germany & 0.2096 & 0.0337 & n/a. & 0.3507 & 0.1396 & 0.0061 & 0.6777 \\
\hline$\underset{0}{0}$ & Italy & 0.6412 & 0.4563 & 0.6310 & n/a. & 0.9056 & 0.5783 & 0.6302 \\
\hline$\stackrel{0}{\partial} \nu^{\sigma}$ & Netherlands & 0.9824 & 0.6060 & 0.4265 & 0.9405 & n/a. & 0.3318 & 0.7416 \\
\hline & UK & 0.2774 & 0.0191 & 0.0440 & 0.0343 & 0.1631 & $\mathrm{n} / \mathrm{a}$. & 0.0241 \\
\hline & US & 0.2536 & 0.3942 & 0.3027 & 0.3760 & 0.1281 & 0.2819 & $\mathrm{n} / \mathrm{a}$. \\
\hline
\end{tabular}

Panel D : Post-Crisis Period (Prob.)

\begin{tabular}{|c|c|c|c|c|c|c|c|c|}
\hline & & & Depende & Variable ( & ct 1 lag) & & & \\
\hline & & Belgium & France & Germany & Italy & Netherlands & UK & US \\
\hline & Belgium & $\mathrm{n} / \mathrm{a}$. & 0.0356 & 0.3000 & 0.2403 & 0.0652 & 0.0132 & 0.3166 \\
\hline $\overrightarrow{0}$ & France & 0.3178 & n/a. & 0.8405 & 0.7653 & 0.9902 & 0.8907 & 0.1411 \\
\hline 氞 & Germany & 0.0144 & 0.1816 & n/a. & 0.3057 & 0.0756 & 0.0479 & 0.7914 \\
\hline$\underset{0}{0}$ & Italy & 0.1658 & 0.1161 & 0.4798 & n/a. & 0.3633 & 0.0426 & 0.9617 \\
\hline & Netherlands & 0.9759 & 0.3604 & 0.6008 & 0.9267 & n/a. & 0.7630 & 0.0002 \\
\hline & UK & 0.1454 & 0.0974 & 0.0773 & 0.6290 & 0.0619 & $\mathrm{n} / \mathrm{a}$. & 0.1165 \\
\hline & US & 0.5090 & 0.3714 & 0.2798 & 0.4513 & 0.7576 & 0.2045 & n/a. \\
\hline
\end{tabular}

Table 6 reflects granger causality analysis in USD denomination. Panel A explains that during the entire observation period, namely May $14^{\text {th }}, 1999$ to December $31^{\text {st }}$, 2019 with 3 lags, there were several countries that predominantly influenced the price index of other countries. Belgium granger causes France, Germany, Italy, Netherlands, and UK with a prob. $<5 \%$. Meanwhile France influenced Belgium, Italy, Netherlands, and UK; Germany granger causes France, Italy, Netherlands, UK, and US. The influence of the US stock index is quite significant on the stock index of Western Europe countries, with granger causes in Belgium, France, and Netherlands. The effect of currency causes increased interdependence across the entire sample.
Panel B, which depicts the pre-crisis observation period, illustrates the strong relationship between the indexes between countries in Western Europe. During this period, there are several countries which are influential as an independent variable, namely the stock indexes of Belgium, France, Germany and the UK. Observations show that time-varying subsamples produce different long-term relationships. During the crisis period, Panel $\mathrm{C}$ explained that Belgium was dominant in granger causes France, Germany, Italy, Netherlands, and UK. Likewise, UK, which was dominant as it granger causes France, Germany, Italy, and the US.

Panel D shows different characteristic in post-crisis period sub-sample compared to the whole period. In this sub-sample, 
France is not a significant independent variable that granger causes the other countries in Western Europe. Likewise, the UK influence that was seen during the crisis period did not have any influence in the post-crisis sub-sample. It can be concluded in Table 6, overall Belgium and Germany Granger cause share prices in Western Europe. Meanwhile, the dominant characteristic of France as an independent variable of long-term relationship does not appear in the post-crisis period.

\section{Short-term Relationships: Impulse Response Analysis Results}

Finally, Wang (2014) also tested short-term causal relationships, which were separated based on the sub-sample observation period. After testing the unit root test and co-integration, the authors used a 7- dimensional VAR, taking into account oneunit shock in modeling changes in volatility during the observation period.

In Table 7 Panel A, the authors describe a generalized impulse response analysis for the whole period covering May $14^{\text {th }}, 1999$ to December $31^{\text {st }}, 2019$. One of the influential countries in this analysis is innovation in the country of Belgium which received a fairly strong response from Italy with reactions to innovation on the first day of 0.9447. Meanwhile, innovation in the Netherlands received a significant negative response from 4 countries including France, Germany, Italy, and the UK, respectively at $-0.4924 ;-1.0889 ;-1.7554$; and -0.5351 on the first day. The innovation in the US country did not get too much reaction to the significant innovation in the Western European countries.

Table 7. Generalized Impulse Response Analysis Source: Author, 2020

\begin{tabular}{|c|c|c|c|c|c|c|c|c|}
\hline \multicolumn{9}{|c|}{ Panel A : Whole Period } \\
\hline \multicolumn{9}{|c|}{ Innovations in Country } \\
\hline \multirow{26}{*}{ 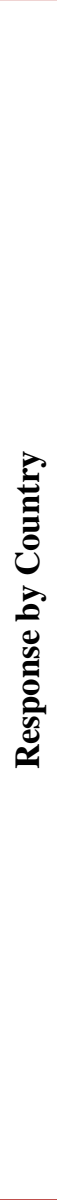 } & & Belgium & France & Germany & Italy & Neth & UK & US \\
\hline & Belgium 1 & 1.0000 & 0.0000 & 0.0000 & 0.0000 & 0.0000 & 0.0000 & 0.0000 \\
\hline & Belgium 2 & 1.1428 & -0.0573 & 0.0227 & -0.0013 & -0.0736 & -0.0250 & -0.0026 \\
\hline & Belgium 3 & 1.1527 & -0.0578 & 0.0200 & -0.0010 & -0.0863 & -0.0257 & 0.0063 \\
\hline & Belgium 4 & 1.1506 & -0.0607 & 0.0193 & -0.0004 & -0.1151 & -0.0233 & 0.0146 \\
\hline & Belgium 5 & 1.1475 & -0.0628 & 0.0184 & -0.0000 & -0.1444 & -0.0208 & 0.0228 \\
\hline & France 1 & 0.0000 & 1.0000 & 0.0000 & 0.0000 & 0.0000 & 0.0000 & 0.0000 \\
\hline & France 2 & 0.1021 & 0.8537 & 0.0678 & 0.0019 & -0.4924 & 0.0079 & -0.0163 \\
\hline & France 3 & 0.1123 & 0.8551 & 0.0592 & 0.0016 & -0.4559 & 0.0079 & -0.0019 \\
\hline & France 4 & 0.1125 & 0.8423 & 0.0582 & 0.0024 & -0.4505 & 0.0122 & 0.0099 \\
\hline & France 5 & 0.1129 & 0.8313 & 0.0565 & 0.0031 & -0.4470 & 0.0163 & 0.0217 \\
\hline & Germany 1 & 0.0000 & 0.0000 & 1.0000 & 0.0000 & 0.0000 & 0.0000 & 0.0000 \\
\hline & Germany 2 & 0.2163 & -0.0229 & 1.0253 & -0.0098 & -1.0889 & -0.0002 & -0.0225 \\
\hline & Germany 3 & 0.2297 & -0.0196 & 1.0133 & -0.0108 & -0.9859 & 0.0031 & -0.0074 \\
\hline & Germany 4 & 0.2349 & -0.0188 & 1.0067 & -0.0116 & -0.9867 & 0.0119 & 0.0045 \\
\hline & Germany 5 & 0.2393 & -0.0174 & 0.9996 & -0.0124 & -0.9842 & 0.0205 & 0.0165 \\
\hline & Italy 1 & 0.0000 & 0.0000 & 0.0000 & 1.0000 & 0.0000 & 0.0000 & 0.0000 \\
\hline & Italy 2 & 0.9447 & -0.3982 & 0.1760 & 0.9419 & -1.7554 & -0.0521 & -0.1905 \\
\hline & Italy 3 & 1.0016 & -0.3331 & 0.1295 & 0.9365 & -1.4398 & -0.0673 & -0.1302 \\
\hline & Italy 4 & 1.0184 & -0.3122 & 0.1090 & 0.9323 & -1.3952 & -0.0577 & -0.0941 \\
\hline & Italy 5 & 1.0314 & -0.2854 & 0.0860 & 0.9277 & -1.3436 & -0.0486 & -0.0562 \\
\hline & Neth 1 & 0.0000 & 0.0000 & 0.0000 & 0.0000 & 1.0000 & 0.0000 & 0.0000 \\
\hline & Neth 2 & 0.0143 & -0.0063 & 0.0065 & -0.0000 & 0.8928 & 0.0003 & -0.0005 \\
\hline & Neth 3 & 0.0154 & -0.0060 & 0.0057 & -0.0000 & 0.8949 & 0.0004 & 0.0006 \\
\hline & Neth 4 & 0.0153 & -0.0063 & 0.0055 & -0.0000 & 0.8913 & 0.0009 & 0.0017 \\
\hline & Neth 5 & 0.0152 & -0.0066 & 0.0053 & -0.0000 & 0.8876 & 0.0014 & 0.0029 \\
\hline
\end{tabular}




\begin{tabular}{rrrrrrrr}
\hline UK 1 & 0.0000 & 0.0000 & 0.0000 & 0.0000 & 0.0000 & 1.0000 & 0.0000 \\
UK 2 & 0.1765 & -0.0748 & 0.0582 & -0.0075 & -0.5351 & 0.9626 & -0.0036 \\
UK 3 & 0.1857 & -0.0724 & 0.0518 & -0.0072 & -0.4996 & 0.9574 & 0.0084 \\
UK 4 & 0.1862 & -0.0784 & 0.0516 & -0.0067 & -0.5137 & 0.9560 & 0.0182 \\
UK 5 & 0.1860 & -0.0829 & 0.0509 & -0.0062 & -0.5273 & 0.9546 & 0.0281 \\
& & & & & & & \\
US 1 & 0.0000 & 0.0000 & 0.0000 & 0.0000 & 0.0000 & 0.0000 & 1.0000 \\
US 2 & 0.0167 & 0.0074 & -0.0185 & 0.0006 & 0.0428 & 0.0057 & 0.9435 \\
US 3 & 0.0185 & 0.0041 & -0.0154 & 0.0005 & 0.0644 & 0.0045 & 0.9399 \\
US 4 & 0.0201 & 0.0039 & -0.0144 & 0.0003 & 0.0768 & 0.0041 & 0.9338 \\
US 5 & 0.0216 & 0.0033 & -0.0132 & 0.0001 & 0.0902 & 0.0038 & 0.9278 \\
\hline
\end{tabular}

Panel B : Pre-Crisis Period

\begin{tabular}{|c|c|c|c|c|c|c|c|c|}
\hline \multicolumn{9}{|c|}{ Innovations in Country } \\
\hline \multirow{36}{*}{ 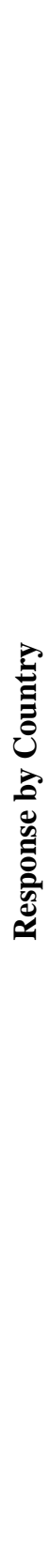 } & & Belgium & France & Germany & Italy & Neth & UK & US \\
\hline & Belgium 1 & 1.0000 & 0.0000 & 0.0000 & 0.0000 & 0.0000 & 0.0000 & 0.0000 \\
\hline & Belgium 2 & 1.1730 & -0.0621 & 0.0556 & -0.0015 & -0.2058 & -0.0339 & 0.0323 \\
\hline & Belgium 3 & 1.1872 & -0.0578 & 0.0427 & -0.0009 & -0.2434 & -0.0290 & 0.0483 \\
\hline & Belgium 4 & 1.1808 & -0.0558 & 0.0420 & -0.0005 & -0.3364 & -0.0206 & 0.0646 \\
\hline & Belgium 5 & 1.1717 & -0.0528 & 0.0394 & -0.0000 & -0.4284 & -0.0113 & 0.0792 \\
\hline & France 1 & 0.0000 & 1.0000 & 0.0000 & 0.0000 & 0.0000 & 0.0000 & 0.0000 \\
\hline & France 2 & 0.0893 & 0.8164 & 0.1929 & -0.0001 & -1.1731 & 0.0422 & 0.0164 \\
\hline & France 3 & 0.0872 & 0.8232 & 0.1519 & 0.0007 & -1.1098 & 0.0561 & 0.0348 \\
\hline & France 4 & 0.0769 & 0.8104 & 0.1566 & 0.0016 & -1.1959 & 0.0695 & 0.0699 \\
\hline & France 5 & 0.0668 & 0.7999 & 0.1550 & 0.0025 & -1.2788 & 0.0845 & 0.1004 \\
\hline & Germany 1 & 0.0000 & 0.0000 & 1.0000 & 0.0000 & 0.0000 & 0.0000 & 0.0000 \\
\hline & Germany 2 & 0.1173 & -0.0637 & 1.0278 & -0.0011 & -1.2958 & 0.0760 & -0.0423 \\
\hline & Germany 3 & 0.1122 & -0.0530 & 1.0030 & -0.0019 & -1.2354 & 0.0910 & -0.0163 \\
\hline & Germany 4 & 0.1024 & -0.0513 & 1.0017 & -0.0023 & -1.3911 & 0.1145 & 0.0156 \\
\hline & Germany 5 & 0.0923 & -0.0467 & 0.9965 & -0.0026 & -1.5274 & 0.1379 & 0.0447 \\
\hline & Italy 1 & 0.0000 & 0.0000 & 0.0000 & 1.0000 & 0.0000 & 0.0000 & 0.0000 \\
\hline & Italy 2 & 0.6257 & -0.5226 & 0.6266 & 0.9214 & -4.1876 & 0.2442 & -0.1154 \\
\hline & Italy 3 & 0.6172 & -0.3493 & 0.4558 & 0.9140 & -4.2605 & 0.3142 & -0.0502 \\
\hline & Italy 4 & 0.5617 & -0.2672 & 0.4589 & 0.9035 & -4.9853 & 0.4100 & 0.0547 \\
\hline & Italy 5 & 0.5032 & -0.1768 & 0.4358 & 0.8939 & -5.6714 & 0.5086 & 0.1459 \\
\hline & Neth 1 & 0.0000 & 0.0000 & 0.0000 & 0.0000 & 1.0000 & 0.0000 & 0.0000 \\
\hline & Neth 2 & 0.0166 & -0.0076 & 0.0203 & -0.0002 & 0.7796 & 0.0036 & 0.0063 \\
\hline & Neth 3 & 0.0162 & -0.0062 & 0.0159 & -0.0003 & 0.7857 & 0.0058 & 0.0070 \\
\hline & Neth 4 & 0.0146 & -0.0056 & 0.0162 & -0.0003 & 0.7674 & 0.0081 & 0.0100 \\
\hline & Neth 5 & 0.0129 & -0.0050 & 0.0159 & -0.0003 & 0.7502 & 0.0105 & 0.0125 \\
\hline & UK 1 & 0.0000 & 0.0000 & 0.0000 & 0.0000 & 0.0000 & 1.0000 & 0.0000 \\
\hline & UK 2 & 0.1554 & -0.0845 & 0.1428 & -0.0047 & -1.0258 & 0.9424 & 0.0124 \\
\hline & UK 3 & 0.1643 & -0.0889 & 0.1074 & -0.0020 & -0.8539 & 0.9345 & 0.0479 \\
\hline & UK 4 & 0.1667 & -0.1024 & 0.1093 & -0.0001 & -0.8668 & 0.9262 & 0.0920 \\
\hline & UK 5 & 0.1680 & -0.1137 & 0.1056 & 0.0018 & -0.8709 & 0.9196 & 0.1313 \\
\hline & US 1 & 0.0000 & 0.0000 & 0.0000 & 0.0000 & 0.0000 & 0.0000 & 1.0000 \\
\hline & US 2 & 0.0138 & 0.0207 & -0.0230 & 0.0008 & -0.0006 & 0.0046 & 0.9622 \\
\hline & US 3 & 0.0163 & 0.0152 & -0.0156 & 0.0008 & -0.0100 & 0.0052 & 0.9455 \\
\hline & US 4 & 0.0170 & 0.0142 & -0.0147 & 0.0009 & -0.0162 & 0.0072 & 0.9272 \\
\hline & US 5 & 0.0173 & 0.0128 & -0.0129 & 0.0010 & -0.0223 & 0.0091 & 0.9097 \\
\hline
\end{tabular}




\begin{tabular}{|c|c|c|c|c|c|c|c|c|}
\hline \multicolumn{9}{|c|}{ Panel C : Crisis Period } \\
\hline \multirow{36}{*}{ 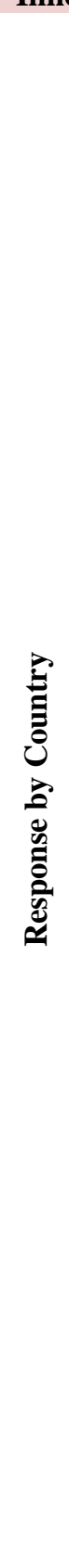 } & & Belgium & France & Germany & Italy & Neth & UK & US \\
\hline & Belgium 1 & 1.0000 & 0.0000 & 0.0000 & 0.0000 & 0.0000 & 0.0000 & 0.0000 \\
\hline & Belgium 2 & 1.1624 & -0.3384 & 0.1189 & 0.0097 & -0.5317 & 0.0561 & -0.0019 \\
\hline & Belgium 3 & 1.0876 & -0.0675 & 0.0194 & -0.0093 & -0.7318 & 0.0827 & -0.1306 \\
\hline & Belgium 4 & 1.1158 & -0.1162 & 0.0232 & -0.0046 & -1.4824 & 0.1023 & -0.1315 \\
\hline & Belgium 5 & 0.9795 & 0.0498 & 0.0178 & -0.0040 & -2.2060 & 0.0902 & -0.0764 \\
\hline & France 1 & 0.0000 & 1.0000 & 0.0000 & 0.0000 & 0.0000 & 0.0000 & 0.0000 \\
\hline & France 2 & 0.3078 & 0.3457 & 0.2331 & 0.0144 & -0.5237 & 0.0638 & -0.0492 \\
\hline & France 3 & 0.1951 & 0.7791 & 0.0877 & -0.0079 & -1.7716 & 0.0901 & -0.2665 \\
\hline & France 4 & 0.2778 & 0.6426 & 0.1165 & -0.0057 & -2.6176 & 0.1319 & -0.2729 \\
\hline & France 5 & -0.0520 & 0.8401 & 0.1076 & -0.0081 & -3.4792 & 0.1363 & -0.1565 \\
\hline & Germany 1 & 0.0000 & 0.0000 & 1.0000 & 0.0000 & 0.0000 & 0.0000 & 0.0000 \\
\hline & Germany 2 & 0.4985 & -0.7859 & 1.3625 & -0.0012 & -1.2924 & 0.0817 & -0.0198 \\
\hline & Germany 3 & 0.4385 & -0.1346 & 1.1352 & -0.0408 & -2.4271 & 0.0759 & -0.3774 \\
\hline & Germany 4 & 0.5327 & -0.4030 & 1.1410 & -0.0186 & -3.9195 & 0.1858 & -0.3791 \\
\hline & Germany 5 & 0.0047 & -0.0582 & 1.1381 & -0.0071 & -4.3878 & 0.1221 & -0.2580 \\
\hline & Italy 1 & 0.0000 & 0.0000 & 0.0000 & 1.0000 & 0.0000 & 0.0000 & 0.0000 \\
\hline & Italy 2 & 2.4860 & -3.0679 & 1.1017 & 1.0561 & -3.5700 & 0.0363 & -0.5434 \\
\hline & Italy 3 & 2.0532 & -0.6647 & 0.2849 & 0.8802 & -4.1643 & 0.0898 & -1.7405 \\
\hline & Italy 4 & 2.5657 & -1.3795 & 0.5712 & 0.8639 & -14.4224 & 0.6963 & -2.0749 \\
\hline & Italy 5 & 0.4824 & 0.2155 & 0.4043 & 0.8579 & -15.5597 & 0.7976 & -1.3255 \\
\hline & Neth 1 & 0.0000 & 0.0000 & 0.0000 & 0.0000 & 1.0000 & 0.0000 & 0.0000 \\
\hline & Neth 2 & 0.0264 & -0.0564 & 0.0185 & 0.0011 & 0.9898 & 0.0065 & -0.0110 \\
\hline & Neth 3 & 0.0157 & -0.0208 & 0.0064 & -0.0006 & 0.9054 & 0.0114 & -0.0294 \\
\hline & Neth 4 & 0.0264 & -0.0316 & 0.0085 & -0.0006 & 0.8115 & 0.0151 & -0.0288 \\
\hline & Neth 5 & -0.0014 & -0.0049 & 0.0075 & 0.0001 & 0.6535 & 0.0165 & -0.0246 \\
\hline & UK 1 & 0.0000 & 0.0000 & 0.0000 & 0.0000 & 0.0000 & 1.0000 & 0.0000 \\
\hline & UK 2 & 0.3734 & -0.6769 & 0.2701 & 0.0021 & 0.2280 & 1.0010 & -0.0978 \\
\hline & UK 3 & 0.1782 & -0.3053 & 0.1662 & -0.0173 & -0.5883 & 1.0106 & -0.4122 \\
\hline & UK 4 & 0.3282 & -0.3336 & 0.1759 & -0.0087 & -2.9939 & 1.0133 & -0.4360 \\
\hline & UK 5 & -0.0759 & 0.0722 & 0.1287 & 0.0090 & -4.6442 & 0.9786 & -0.2792 \\
\hline & US 1 & 0.0000 & 0.0000 & 0.0000 & 0.0000 & 0.0000 & 0.0000 & 1.0000 \\
\hline & US 2 & 0.0196 & -0.0024 & -0.0089 & -0.0017 & 0.0280 & 0.0116 & 0.8518 \\
\hline & US 3 & 0.0709 & 0.0572 & -0.0145 & -0.0109 & 0.2442 & -0.0267 & 0.7945 \\
\hline & US 4 & -0.0028 & 0.0109 & -0.0019 & -0.0064 & 0.1040 & 0.0277 & 0.7814 \\
\hline & US 5 & -0.0337 & 0.0145 & 0.0174 & -0.0091 & -0.0937 & 0.0340 & 0.7520 \\
\hline
\end{tabular}

Panel D : Post-Crisis Period Innovations in Country

\begin{tabular}{|c|c|c|c|c|c|c|c|c|}
\hline \multirow{10}{*}{ 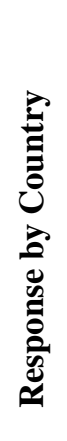 } & & Belgium & France & Germany & Italy & Neth & UK & US \\
\hline & Belgium 1 & 1.0000 & 0.0000 & 0.0000 & 0.0000 & 0.0000 & 0.0000 & 0.0000 \\
\hline & Belgium 2 & 0.9749 & -0.0262 & 0.0117 & 0.0005 & 0.0617 & -0.0076 & 0.0060 \\
\hline & Belgium 3 & 0.9510 & -0.0510 & 0.0229 & 0.0009 & 0.1210 & -0.0148 & 0.0116 \\
\hline & Belgium 4 & 0.9281 & -0.0743 & 0.0335 & 0.0013 & 0.1780 & -0.0216 & 0.0167 \\
\hline & Belgium 5 & 0.9064 & -0.0962 & 0.0436 & 0.0016 & 0.2327 & -0.0281 & 0.0214 \\
\hline & France 1 & 0.0000 & 1.0000 & 0.0000 & 0.0000 & 0.0000 & 0.0000 & 0.0000 \\
\hline & France 2 & -0.0247 & 0.9478 & 0.0116 & 0.0013 & 0.2006 & -0.0067 & 0.0128 \\
\hline & France 3 & -0.0481 & 0.8981 & 0.0227 & 0.0025 & 0.3947 & -0.0131 & 0.0250 \\
\hline & France 4 & -0.0703 & 0.8507 & 0.0330 & 0.0036 & 0.5824 & -0.0191 & 0.0365 \\
\hline & France 5 & -0.0913 & 0.8055 & 0.0428 & 0.0047 & 0.7639 & -0.0246 & 0.0473 \\
\hline
\end{tabular}




\begin{tabular}{|c|c|c|c|c|c|c|c|}
\hline Germany 1 & 0.0000 & 0.0000 & 1.0000 & 0.0000 & 0.0000 & 0.0000 & 0.0000 \\
\hline Germany 2 & -0.0207 & -0.0553 & 1.0057 & 0.0000 & 0.3154 & -0.0063 & 0.0139 \\
\hline Germany 3 & -0.0402 & -0.1080 & 1.0107 & 0.0000 & 0.6214 & -0.0122 & 0.0271 \\
\hline Germany 4 & -0.0584 & -0.1581 & 1.0152 & -0.0000 & 0.9184 & -0.0178 & 0.0397 \\
\hline Germany 5 & -0.0755 & -0.2058 & 1.0191 & -0.0002 & 1.2066 & -0.0230 & 0.0516 \\
\hline Italy 1 & 0.0000 & 0.0000 & 0.0000 & 1.0000 & 0.0000 & 0.0000 & 0.0000 \\
\hline Italy 2 & -0.1246 & -0.0936 & 0.0620 & 0.9943 & 0.1179 & -0.0374 & 0.0308 \\
\hline Italy 3 & -0.2432 & -0.1806 & 0.1207 & 0.9885 & 0.2326 & -0.0727 & 0.0591 \\
\hline Italy 4 & -0.3560 & -0.2613 & 0.1762 & 0.9826 & 0.3440 & -0.1059 & 0.0850 \\
\hline Italy 5 & -0.4633 & -0.3362 & 0.2287 & 0.9765 & 0.4525 & -0.1372 & 0.1088 \\
\hline Neth 1 & 0.0000 & 0.0000 & 0.0000 & 0.0000 & 1.0000 & 0.0000 & 0.0000 \\
\hline Neth 2 & -0.0020 & -0.0022 & 0.0012 & -0.0000 & 0.9946 & -0.0007 & 0.0016 \\
\hline Neth 3 & -0.0039 & -0.0043 & 0.0024 & -0.0000 & 0.9895 & -0.0014 & 0.0031 \\
\hline Neth 4 & -0.0057 & -0.0063 & 0.0035 & -0.0000 & 0.9845 & -0.0021 & 0.0045 \\
\hline Neth 5 & -0.0074 & -0.0082 & 0.0045 & -0.0000 & 0.9796 & -0.0027 & 0.0059 \\
\hline UK 1 & 0.0000 & 0.0000 & 0.0000 & 0.0000 & 0.0000 & 1.0000 & 0.0000 \\
\hline UK 2 & -0.0438 & -0.0463 & 0.0235 & 0.0003 & 0.0637 & 0.9778 & 0.0178 \\
\hline UK 3 & -0.0851 & -0.0896 & 0.0457 & 0.0006 & 0.1253 & 0.9566 & 0.0344 \\
\hline UK 4 & -0.1241 & -0.1300 & 0.0666 & 0.0008 & 0.1849 & 0.9362 & 0.0498 \\
\hline UK 5 & -0.1610 & -0.1676 & 0.0863 & 0.0009 & 0.2427 & 0.9167 & 0.0641 \\
\hline US 1 & 0.0000 & 0.0000 & 0.0000 & 0.0000 & 0.0000 & 0.0000 & 1.0000 \\
\hline US 2 & -0.0056 & -0.0016 & -0.0017 & -0.0002 & 0.2344 & 0.0006 & 0.9754 \\
\hline US 3 & -0.0114 & -0.0033 & -0.0032 & -0.0004 & 0.4606 & 0.0012 & 0.9517 \\
\hline US 4 & -0.0173 & -0.0053 & -0.0044 & -0.0006 & 0.6789 & 0.0016 & 0.9289 \\
\hline US 5 & -0.0233 & -0.0073 & -0.0055 & -0.0008 & 0.8895 & 0.0019 & 0.9069 \\
\hline
\end{tabular}

In Table 7 Panel B, the authors describe a generalized impulse response analysis in the pre-crisis period which includes the observation period May $14^{\text {th }}, 1999$ to December $31^{\text {st }}, 2007$. One of the influential countries in this analysis is the innovation in the country of Belgium which received a fairly strong response from Italy, with the reaction to innovation on the first day of 0.6257. Meanwhile, innovation in the Netherlands received a significant negative response from 4 countries including France, Germany, Italy, and the UK, respectively at $-1.1731 ;-1.2958 ;-4.1876$; and -1.0258 on the first day. The innovation in the US country did not get too much reaction to the significant innovation in the Western European group of countries. Overall, Italy is the most sensitive country in the country's response to innovations that occurred in other Western European countries during the pre-crisis period.
In Table 7 Panel $\mathrm{C}$, generalized impulse response analysis is observed in the crisis period which includes the observation period January $1^{\text {st }}, 2008$ to December $31^{\text {st }}$, 2012. Just like the results in the pre-crisis period, innovation in the country of Belgium which received a strong response from Italy with reactions to innovation on the first day of 2.4860 which is stronger than previous 0.6257 . Likewise, there was an increase in response activity for the innovation of the Netherlands, which also received a negative response from Belgium of -0.5317 on the first day. In this subsample it was also confirmed that Italy was the most sensitive country in the country's response to innovations that occurred in other Western European countries, including the US, which recorded a response of -0.5434 on the first day.

In Table 7 Panel D, the author describes generalized impulse response analysis in the post-crisis period which includes the 
observation period January $1^{\text {st }}, 2013$ to December $31^{\text {st }}, 2019$. In contrast to previous observations, the response of Western Europe to other countries' innovations is not significant enough in the subsample Panel D. However, the results obtained are consistent with the results of the whole period which show that innovation in the US does not really get a reaction to significant innovation in the western European group of countries.

\section{Conclusion}

The author focuses on short-term and longterm causal relationships with 6 stock exchanges in Western Europe that are quite dominant and actively traded, including UK, Germany, France, Belgium, Netherlands, Italy, and US. Apart from using the local currency, the authors convert the closing stock price of each country in USD. The observation period is also separated into 3 sub-samples to represent the pre-crisis, crisis, and post-crisis periods.

Based on the Johansen Test, it was found that the conversion of local currency in USD denominations had an effect on increasing the interdependence shown in the pre-crisis observation. However, overall, the long-term relationship shown by the co-integrating vector is quite consistent across the entire sample and subsample used. Long-term relationships were also tested by granger causality showing different characteristics in each sub-sample. However, it can be observed that there are several countries that can predominantly influence the price index of other countries in Western Europe. In the whole sample, Belgium, Germany, and the US should be considered as independent variables that granger causes other Western Europe countries.

Short-term causal relationships were tested by the Generalized Impulse Response Analysis, which considers one-unit shock. Overall, the innovation in Belgium received a strong positive response from Italy. Meanwhile, innovation in the Netherlands received a significant negative response from 4 countries including France, Germany, Italy and the UK. In various subsamples, it can be concluded that Italy is the most sensitive country in response to innovations that have occurred in other Western European countries. The innovation in the US country did not get too much reaction to the significant innovation in the western European group of countries.

In the end, knowledge of causal relationships both short and long term; can be useful for investors in implementing risk management and portfolio diversification. The importance of this knowledge is in line with the argument of Gupta et.al (2019) regarding the importance of diversification in order to achieve maximum returns by considering risks. In addition, investors can also observe the dependence of Western Europe countries with the US in relation to transformation in order to emphasize the financial crisis and macroeconomic interdependence highlighted by Dervis \& Kharas (2011).

In addition, significance implications for investors are captured in Wang (2014) research, as market index co-movement is crucial for diversification strategy and risk management purposes. Further research is suggested to be able to sharpen the analysis by adding a sample of countries in region and taking into account the parameters of trading volume and stock price volatility.

\section{References}

Ahmedov, Z., \& Bessler, D. (2011). Structure of interdependencies among international stock markets and contagion patterns of 2008 global financial crisis. Agricultural Economics Association Annual Meeting

Bessler, D., \& Yang, J. (2003). The structure of interdependence in international stock market. Journal of International Money and Finance, 22(2), pp. 261-287. 
Cheung, W., Fung, S., \& Tsai, S. (2010). Global capital market interdependence and spillover effect of credit risk: evidence from the 2007-2009 global financial crisis. Applied Financial Economics, 20(1-2), pp. 85-103.

Dervis, K. \& Kharas. (2011). Introduction: macroeconomic policy interdependence and the G-20. Think Tank 20 Macroeconomic Policy Interdependence and the G-20, 2011(April), pp. 15.

Gupta, S. \& Kaur. (2019). Dynamics of interdependencies of Asian stock markets: an empirical study. The IUP Journal of Applied Finance, 25(1), pp. 21-35.

Johansen, S. (1911). Estimation and hypothesis testing of co-integration vectors in Gaussian vector autoregressive models. Econometrica, 59(6), pp. 1551-1580.

Kumar, R. (2019). Does trade interdependency lead linkages between stock markets? A case of South Asian countries. International Journal of Emerging Markets, 14(3), pp. 490-506.

Rahman, M.S., Othman \& Shahari, F. (2017). Testing the validation of the financial cooperation agreement among ASEAN 3+ stock markets. International Journal of Emerging Markets, 12(3), pp. 572-592.

Samadder, S., Bhunia, A. (2018). Integration Between Indian Stock market and developed stock markets. Journal of Commerce and Accounting Research, 7(1), pp. 13-23.

Vodenska I, Aoyama H, Fujiwara Y, Iyetomi H, \& Arai Y. (2016). Interdependencies and causalities in Coupled Financial Networks. PLoS ONE, 11(3), pp. 1-32.
Wang, L. (2014). Who moves East Asian stock markets? The role of the 20072009 global financial crisis. Journal of International Financial Markets, Institutions and Money, 28, pp. 182203. 